\title{
IV. Klientelsysteme in Italien: im Norden und im Mezzogiorno
}

\author{
Einleitung zur Diskussion
}

\section{Anthony Molbo}

\section{Patronage and the State in Early Modern Italy}

"Les clientèles ont existé à toutes les époques", writes Yves Durand in the opening article of the Festschrift recently dedicated to Roland Mousnier, one of the historians most directly responsible for underscoring the importance of clientage and of patronage in early modern European society ${ }^{1}$. In Mousnier's own vision, clientage has been a ubiquitous phenomenon; it, and fidelity (fidélité), the sentiment which underlies it, occupy such an unmistakably central rôle as to merit the launching of an "enquête internationale" whose object it would be to study their manifestations in as disparate and diverse human relationships as the relation "Maître-Fidèle", "la fidélité des époux", and even "la fidélité des croyants" number of different directions and may well run the risk, as Giorgio Chittolini points out in his paper, of falling "nelle genericità che talora si accompagnano ai discorsi sulle

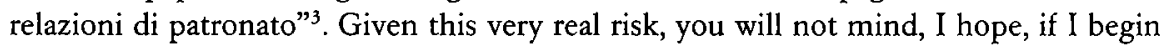
my observations by focusing my attention, at least initially, on the narrow field of my own specialization, the history of late mediaeval Florence.

The field of Florentine historiography has been particularly vibrant in the past thirty-odd years. Since the publication in 1955 of Hans Baron's Crisis of the Early Italian Renaissance, and particularly in the anglophone world, dozens of historians have studied the history of that city. Some have focused their attention on Florentine social structures, others on economic development, still others on the history of humanism.

${ }^{1}$ Yves Durand, Clientèles et fidélités dans le temps et dans l'espace, in: Hommage à Roland Mousnier - Clientèles et fidélités en Europe à l'époque moderne (Paris 1981) 3-24.

${ }^{2}$ First published in the Revue historique of 1975 , Mousnier's call for this enquête is reprinted in the volume cited in note 1, XXI-XXIII.

${ }^{3}$ Giorgio Chittolini's contribution to this volume, S. 243-259. 
Yet, from Baron himself to Gilbert and Rubinstein among the older, German-born generation, to Becker, Brucker, Martines and Weinstein who represent the first native American group of Florentinists, to the even younger generations in England, Australia and the U.S. who entered the field more recently, one of the constant historiographic preoccupations has been the nature of the Florentine state. This preoccupation is not accidental. Baron's own magisterial interpretation of early Renaissance humanism appeared in the very same year of the Tenth International Congress of Historical Sciences when, perhaps, the key issues discussed were those raised by F. Hartung and R. Mousnier in their joint presentation regarding "Quelques problèmes concernants la monarchie absolue" . In the very next year, 1956, Federico Chabod presented in Paris his influential essay, significantly entitled "Y a-t-il un Etat de la Renaissance?"5 Several other scholars joined the discussion in the years following. Clearly the question at hand was not new. Arguably, as far as Italy goes, Burckhardt's own formulation of the "state as a work of art" (Der Staat als Kunstwerk) had anticipated some of the subsequent discussion. But the question of the nature of the modern state was very much in the air during the very years when the anglophone historiography on Florence was getting off the ground. It was inevitable that the more general discussion would have had a bearing on the orientation of the then budding field of Florentine historiography.

What, then, can one ask, was the interpretation of the Florentine state which emerged from the work of these scholars? Very briefly, we can compare three books published within three years of each other: Nicolai Rubinstein's The Government of Florence Under the Medici (London, 1966); Marvin Becker's Florence in Transition, 2 vols. (Baltimore, 1967-8); and Lauro Martines' Lawyers and Statecraft in Renaissance Florence (Princeton, 1968). When these works were first published, there was a rush of discussion which tended to dwell upon their differences and on the particularity of each author's interpretation. Rubinstein's work viewed the development of Florentine politics from the perspective of electoral politics, Becker's from that of fiscal policy, while Martines examined, above all, the contributions of lawyers to the functioning of the Florentine government. Yet, despite these differences, the conclusions of all three are strikingly similar. Rubinstein, Becker, and Martines were concerned with describing a historical process which sprouted into a form of state which, whether or not one calls it modern, was very different from the governmental forms which had predated it. Thus, Rubinstein analyzed the Florentine "constitution" whose manipulation enabled the Medici to concentrate in their hands and those of their trusted allies the vital electoral organisms upon which they relied to control power. Becker, for his part, emphasized the emergence of "public law" which, in the course of the Renaissance, supplanted "private immunities", while "traditional forms of government intimately associated with the era of the medieval commune dissolved". And in another passage,

${ }^{4}$ F. Hartung \& R. Mousnier, Quelques problèmes concernant la monarchie absolue, in: Relazioni del X Congresso internazionale di scienze storiche (Firenze 1955) IV, 3-55.

s Originally delivered as a lecture at the Sorbonne in 1956, Chabod's text was first published in 1958. It is now found in his Scritti sul rinascimento (Torino 1967) 605-621 
taken from a justly acclaimed article of his, Becker compared the Florentine state of the fifteenth century to the "proverbial Leviathan", an institution which had emerged from the "chrysalis of the Commune" to become the state of the Renaissance 6 . Finally, Martines amphasized the strengthening, both in Florence and in Milan, of the powers of the executive and of the centralized government, which, in some of its manifestations he argued, was leading in the direction of the "modern absolutist state". Of the three historians to whose work we just referred, Martines was the most cautious and tentative in formulating his generalizations on the possible modernity of the Renaissance state. Yet, even he tended to emphasize the centralizing and modernizing aspects of the new governments which emerged in the fifteenth century. What unifies - at a conceptual and interpretive level - these three studies as well as other interpretations of those years is their general neglect of particularistic institutions and tendencies which eroded the power of the central government. What unifies them even more is their emphasis on such categories as bureaucracies, executive power, territorially united states, elements which underscored the modernity of the Renaissance state.

Let us now look at three other works on Florentine history, written more recently: Ronald Weissman's Ritual Brotberbood in Renaissance Florence (New York, 1980); D. V. and F. W. Kent's Neigbbors and Neigbborbood in Renaissance Florence (Locust Valley, N.Y., 1982); and Richard Trexler's long article of 1983, devoted to the Ciompi revolt and entitled "Neighbors and Comrades". In none of these three does one detect a particularly keen interest in the history of the state. Quite to the contrary. Where Rubinstein, Becker and Martines focussed their collective attention upon government institutions and were inclined to define the term "Florence" as a political and ideological entity, these younger scholars have focussed their attention upon a set of categories which, on the surface of things, has very little to do with the Florentine state. In his own analysis, Weissman concludes that the Florentines of the fourteenth and fifteenth centuries lived in a world dominated by their neighborhoods, within which they developed their most significant social relations. Florence itself, rather than perceived as an entity whose unity was expressed in its very government, is perceived by Weissman as a conglomerate of small villages, of quasi-autarchic neighborhoods which delimited and defined the social and intellectual horizons of most Florentines. In vain will one look to Weissman's book for an explanation of the development of the Florentine state in the fifteenth century. The Kents pursue the very same theme in their study of one of Florence's sixteen administrative units, the gonfalon Lion Rosso. Where Weissman, before, had overlooked the preceding discussions on the Renaissance state, the Kents do take them into account. Yet, they appear impatient with the questions raised by previous scholars. The explanations regarding "the 'statist' pressure" allegedly exerted in the fifteenth century "hardly seem to do justice to the complex social and political situation" which they detect in Florentine society. It is the neighborhood which emerges as the dominant political and social category of the Kents' narrative, a category which represented a "distinct and individual corporate world", one which "served

${ }^{6}$ Economic Change and the Emerging Territorial State in: Studies in the Renaissance XXX (1966) 7-39. 
as an intermediary between the citizen and the commune"7. Very much the same picture is established in Trexler's article, one of whose over-riding conclusions is that neighborhood associations helped create the crucial solidarities at the time of the Ciompi revolution ${ }^{8}$.

Thus, it appears that anglophone historiography on late mediaeval Florence has completed an interpretive trajectory of some magnitude during the last dozen or so years. From a preoccupation with discovering the roots of the modern state in the history of Florence, a number of American and Australian scholars are now attempting to demonstrate that the city's much vaunted modernity evaporates when Florentine history is examined through the prism of concepts appropriated from the social sciences, above all anthropology 9 . This is not the occasion in which to assess the contributions made by this younger generation of historians. Nonetheless, what is directly relevant to our proceedings is the fact that the subject of patronage hardly appeared in the work of the first three scholars to whose monographs we already referred, while, without any question at all, it has dominated the interpretation of Weissman, the Kents and Trexler. Clearly, this is not a coincidence. For it will be my claim in the balance of my brief presentation that it was difficult, if not altogether impossible, to conceive and discuss the subject of patronage so long as the dominant historiographic preoccupation was that of tracing the history of the "modern state". Chabod's early vision of a "stato impersonale, razionale, legalistico, burocratico, livellatore" ${ }^{10}$ could easily be accommodated to Becker's view of the Florentine state as the "proverbial Leviathan", but could hardly come to terms with Weissman's "small-scale, face-to-face society of the Renaissance town". And, to follow Weissman's explanation, it was precisely the patron "who provided the requisite links ... in such a fragmented world"11.

In some important respects, the interpretive shifts evident in the field of Florentine historiography are themselves reflections of wider changes of interpretation which characterize the debate regarding the nature of the early modern state in Italy. Increasingly, the discussion regarding the modern state has distanced itself from the positions embraced by Antonio Anzilotti, Francesco Ercole and even by the young Chabod himself. During the first half of this century the roots of the modern state were found in the very governments which emerged in Italy during the late mediaeval and early modern eras. The "Renaissance state" was marked by a number of characteristics: 'the emergence of a nationalist spirit, the growth of governmental responsibilities, the slow taking shape of bureaucracies and the consequent increase in the administrative efficiency with which the new governments were run; conversely, the dilution of old feudal obligations, the levelling out of old particularistic institutions, the erosion of regionalism - all these were themes upon which earlier scholars had concentrated their

${ }^{7}$ Quotation found on pp. 5 and 8.

${ }^{8}$ Social Analysis 14 (December 1983) 53-106.

9 A notable exception to this generalization is Alison Brown's recent incisive article: Florence, Renaissance and Early Modern State: Reappraisals, in: Journal of Modern History LVI (1984) $285-300$.

${ }^{10}$ Federico Chabod, Lo stato di Milano nell'impero di Carlo V (Milano 1934) 175.

11 Weissman, op. cit., 22-23. 
attention. Yet, even Chabod himself, in the years immediately following his Parisian address on the Renaissance state, had presented a much more nuanced and complex image of the Milanese state in the sixteenth century, a picture which, if dominated by certain modernizing elements (such as the "forte organizzazione centralizzata" and an "organizzazione burocratica centrale") also contained components endowing it with "caratteristiche di stampo tutt'altro che moderno"12. This sensitivity to the complexity of the early modern Italian states and to the absence of a linear growth from the mediaeval commune to the modern state (conceived in essentially Weberian terms) was expressed even more strongly some years following Chabod's death by Marino Berengo. In 1967 he seemed to turn the old generalizations on their head when he asserted that the most dominant characteristic of the sixteenth century Italian states, far from being their centralizing tendencies, was the "trionfante particolarismo dei corpi", a phenomenon which in many senses represented an inversion of a course already undertaken by some fifteenth century republican régimes ${ }^{13}$. In more recent years, thanks primarily to the reflective syntheses of a number of historians, among whom Chittolini, Fasano, Galasso and Musi have presented particularly persuasive arguments, a greater balance has been struck in the general interpretation of explanations of Italian state-building ${ }^{14}$. Thus, Chittolini has argued that there is a nearly contrapuntal relationship between the gradual increase in the authority of the sixteenth century prince and the parallel propensity of the new states to recognize and legitimate old bodies and local institutions. As was the case in other parts of Europe, Chittolini identified in the Italian course of political events the same "dualism" between a "potere centrale o 'sovrano' ... e ... una serie di nuclei territoriali compatti che avevano rinunciato forzatamente all'indipendenza, ma non alla difesa delle loro libertà". And Fasano, although expressing some doubts about Chittolini's tendency to discuss Italian history in light of a presumed "crisis" of the sixteenth century, adopts a similarly balanced and complex view. In her most recent discussion of these problems, she suggests that central and peripheral institutions shared a "complementarità di funzioni", a state of affairs, at least in the state of Tuscany, not only tolerated but encouraged by the prince.

There is a great deal of historical work recently completed which reinforces the view of the early modern Italian state as neither mediaeval and feudal (in the sense that it fell victim to deeply rooted centrifugal forces inherited from the past), nor as the precocious anticipation of modernizing tendencies which would emerge later in other

${ }^{12}$ Federico Chabod, Stipendi nominali e busta paga effettiva dei funzionari dell'amministrazione milanese alla fine del cinquecento, in: Miscellanea in onore di Roberto Cessi (Roma 1958) 251.

${ }^{13}$ Marino Berengo, Il Cinquecento, in: La storiografia italiana negli ultimi vent'anni ... (Milano 1968) I, 490.

${ }^{14}$ For Chittolini: La formazione dello stato regionale e le istituzioni del contado (Torino 1979) and his Introduzione to his La crisi degli ordinamenti comunali e le origini dello stato del Rinascimento (Bologna 1979). For Fasano, Lo stato di Cosimo I (Firenze 1973), her Introduzione, to her Potere e società negli stati regionali italiani fra '500 e '600 (Bologna 1978) and Gli Stati d'Italia centro-settentrionale tra quattro e cinquecento: continuità e trasformazioni, in: Società e storia VI (1983) 617-639. For Galasso, Potere e istituzioni in Italia dalla caduta dell'Impero romano a oggi (Torino 1974), and for Musi, Stato e pubblica amministrazione nell'ancien regime (Napoli 1979). 
European societies. Rather, the same complex balance of forces, institutions and tendencies seem to characterize Italian history as that identified by Oestreich, Gerhard and Mousnier in their discussions of Transalpine political history. For Italy itself, F. Diaz's description of Cosimo I's attempt to "ménager" a Florentine tradition by solicitously preserving certain institutional and political traditions of long standing while creating his stato nuovo; R. Burr Litchfield's thorough demonstrations that the functionaries of the new Medicean state were drawn largely from the city's traditional ruling class; Fasano's own studies on the relationship of Florence to its subject cities and territories and on the accommodation reached between provincial élites and the ducal court of Florence; Cozzi's studies on the administration of justice in Venice and Sicily; de Mesquita's and Chittolini's analyses of the balance of forces between the Milanese signoria and the great feudal families of Lombardy - all these studies and many more underscore the variety of arrangements possible in the course of the constant dialectic between centrifugal and centripetal forces at work on the Italian scene during the late mediaeval and early modern centuries ${ }^{15}$. And if it is true as Galasso has argued that Italy during that era was a "pluralità di formazioni politiche", if its history was "una storia parallela delle singole formazioni politiche presenti nel paese", it might also be possible to argue that the country's multiple histories were infused with a certain degree of unity by their common experiences in struggling to provide a balance between center and periphery, centralizing and dispersive forces, attempts to preserve past privileges and those aimed at creating new ones. But, out of their collective research little seems now to remain of Chabod's early vision of the Renaissance state as an "impersonal, rational, legalistic, bureaucratic, levelling" entity. Efforts to attain that goal in sixteenth-seventeenth century Italy would fail as power remained fragmented, dispersed, refracted through old and new institutions.

The topic of patronage in Italian society emerges as an important subject of study precisely because of the realization regarding the nature of political power and the character of the states which governed the peninsula. Patronage in the era from the fiftenth to the eighteenth centuries operated very much in the same political space which it had occupied before: in the interstices of the state, offering members of various groups, orders, associations or geographical entities access to rewards, offices, prizes, protection, fiscal advantage, judicial clemency and the like. In this sense, it may be possible to suggest that the political changes of the early modern period, regardless of the particular configuration in each state, left enough room available for the survival of a political culture based on the institution of patronage.

Indeed, the more one studies various periods of Italian history, the more one is struck by the longevity and durability of this institution. Paul Veyne recently wrote a masterful study of clientage in the late Roman Empire, in which he argued that "le Bas-Empire offre dans bien des domaines le spectacle de la clientèle". Significantly, he added that those who perceive the persistence of clientage as a reflection of the weak-

\footnotetext{
${ }^{15}$ For full and more extensive bibliographic references the reader is advised to consult the "Introduzioni" written by Chittolini and by Fasano to their respective anthologies cited in the preceding note.
} 
ness of the Roman state fail to understand how essential patronage was to the very survival of the government itself ${ }^{16}$. Cinzio Violante, writing on eleventh century Milan, refers, without particular comment, to the patronage network cultivated by bishop Arimberto ${ }^{17}$. And when we move up in time to the history of the fourteenth-fifteenth century communes we encounter myriads of examples, many of them studied at great length in recent years, which illustrate the resilience and adaptability of the institution of patronage. Lorenzo de' Medici's often quoted statement, in which he sought to explain the reasons which induced him to follow in his father's and grand-father's steps and assume the leadership of the city, is itself a clear and colorful reference to the strength of the patronage system in that most Renaissance of Italian cities: “... mal volentieri accettai, e solo per conservazione degli amici e sostanze nostre, perché a Firenze si può mal vivere senza lo stato."18 All throughout the entire chronological span of Italian history, down to Jeremy Boissevain's, Sydel Sylverman's and Paul Littlewood's recent studies on contemporary Italy, the institution of patronage is ubiquitous, a sort of deep structure ineradicable from Italian political culture ${ }^{19}$.

The three studies presented to our conference fall, I believe, within the historiographic tradition sketched above. In examining the efforts of Emanuele Filiberto, Duke of Savoy, to create a state ex novo, Barberis focusses his attention on the plan to establish a citizen militia. The object of this initiative was to undermine, if not eliminate, old feudal ties between local lords and their subjects and to create direct ties of dependence between the Duke and his subjects. But the effort failed, precisely, as Barberis notes, because the "mediazione di elementi locali è oggettiva, necessaria e inquinante". So, in the end, the Duke was forced to take into account the local situation (the "microconflittualità locali") and to rely on the very notables, whose position he had initially attempted to subvert, as the key elements of his army and as the agents through whom local control could be exercised in the provinces of the Duchy. Thus, the process of "state-building" was subjected precisely to the type of accommodations which, as we already noted, historians of early modern Italy have highlighted in their recent work. It may be worth observing that the dynamic element in the picture drawn by Barberis is represented by the local forces which, it would appear, by virtue of tradition and the web of complex material and power interests, impeded the realization of Emanuele Filiberto's ambitious plans. In some important respects, Chittolini presents a slightly different image in his own essay. For, in studying the relationships of patronage which grew out of feudal grants awarded in northern Italy from the fifteenth to the seventeenth centuries, he seems to indicate that in his estimation the crucial agent was the central government which, at some points was able to impose its authority, while

\footnotetext{
${ }^{16}$ Clientèle et corruption au service d'état: La vénalité des offices dans le bas empire romain, in: Annales XXXVI (1981) 339-361.

${ }^{17}$ Cinzio Violante, Società milanese nell'età precomunale (Bari 1974) 232 and following.

${ }^{18}$ Lorenzo de'Medici, Ricordi, in: W. Roscoe, The Life of Lorenzo de'Medici (London 1902) 426.

19 Jeremy Boissevain, Patronage in Sicily, in: Man I (1966) 19-33; Paul Littlewood, Strings and Kingdoms - The Activities of a Political Mediator in Southern Italy, in: Archives européennes de sociologie XV (1974) 33-51; Sydel Sylverman, Three Bells of Civilization: The Life of an Italian Hill Town (N.Y. 1975).
} 
at others, because of the prevailing diplomatic and military situation, was constrained to come to terms with established feudal lords, or to award new feudal grants to landowning or military families. Thus, in the generally fluid and unsettled world of fifteenth century politics, as territorial states were being created, political spaces were made available to local lords who, drawing on their own authority and wealth, gathered about themselves clientelles and managed to insert themselves in the power structures of their territorial states. In the Valpadana of the sixteenth and seventeenth centuries, on the other hand, when the central government was in a position to wield its own power directly and effectively, the number and extent of feudal grants were severely limited, so that the clientage relationships based on these grants diminished in importance. Thus, implicitly but forcefully, Chittolini questions the views of some recent scholars, Ruggiero Romano and Philip J. Jones above all, that the overarching and most significant development of Italian history from the late fourteenth to the seventeenth century was the continuous "refeudalization" of central and northern Italian societies. Not so, suggests Chittolini, for the changes of the sixteenth and seventeenth centuries represented a substantial break from the preceding developments. Chittolini does add that an outcome of these changes was the establishment of new networks of patronage. He does not identify these, although I suspect that it would be important to examine the shifting patterns of patronage in an area subjected to a noticeable increase of central power. Lepre's paper, broader in scope and more widely ranging than the others, represents an effort to explore the underlying causes explaining the resilience and longevity of clientelar structures in a vast area of the peninsula (the Mezzogiorno), over a long period of time, from the late Middle Ages to the early nineteenth century. In many respects, his interpretation neatly complements and expands upon points already made here. One of the keys to Lepre's interpretation is his insistence on the vital importance of feudalism in the South. It was that region's feudal structures which left a pervasive cultural legacy (" $\left[l^{\prime}\right]$ indispensabilità del potente veniva ... a radicarsi profondamente nella mentalità contadina") and a highly fragmented political and economic situation. A multiplicity of baronial curias dominated the region and within each barony, where peasants were kept largely isolated from the regional market-place, overlapping and complementary patronal webs were fashioned by the baron's agents, each in charge of a specific area of administration. Once the barons themselves took up residence in Naples, where they could be kept under the surveillance of the royal court, the feuds were left almost entirely under the daily administration of the baron's agents. New centers of clientage were now forged in baronial palaces in Naples, so that in urban centers and rural areas, because of the traditional fragmentation of political power and the parallel survival, over so long a period of time, of feudal structures and traditions, patron-client relations retained their importance.

The general picture which emerges from these papers is clear enough: The political changes introduced in Italy during the early modern era, whatever their import and extent, seem to have borne little or no influence at all on the continuing viability of patronage and clientage. Whether we examine Piedmont, Lombardy or the South, we discover that patronage flourished in the early modern period. We are likely to have made the very same discovery had we cast our attention on the Veneto, or Liguria, or 
Tuscany, had we concentrated on cities well inserted in the market economy or on hamlets perched on the Appennines or the Alps. And where, as all three papers suggest, one form of patronage was forced out of the scene because of political changes, it was replaced by another form of patronage. It would seem, therefore, that, at least on this score, Mousnier's warning had been quite right: Patronage emerges as a deep structure, a kind of timeless fixture on the political landscape. But, if that is so, a question inevitably comes to mind: Does such a deep structure, whose permanence seems eternal, have a history of its own? After all, should it not be possible to identify and measure the changes over such a longue durée just as historians, recently, have been able to reconstruct the histories of other seemingly timeless and ahistorical subjects? More specifically, what was the influence upon patron-client relationships of the shifting economic, political and fiscal structures of various Italian societies during the late mediaeval and early modern eras? There is a need to inject a temporal dimension into the study of patronage, to see it in a specific and time-bound context. Even the most recent study on the subject, Jean-Claude Waquet's book on corruption in seventeenth and eighteenth century Florentine society, tends to force the study of patronage out of its particular historical context into a conceptual framework just as easily adaptable to ancient Rome, to early modern Europe, and to the contemporary U.S. and U.S.S.R. ${ }^{20}$ !

So, in conclusion, we come to the question of definitions. In my estimation, an attempt to define patronage in all its manifold manifestations is likely to be exceedingly difficult, perhaps even fruitless. The discussion we held in our colloquium kept raising a series of seemingly insoluble problems precisely, it appears, because it is difficult to offer a valid and acceptable comparison between historical situations as different as England was from Spain, and Scotland from Italy. Maczak in his opening remarks warned us of this very problem when he said that "every generalization about patronage finds its contradiction in another case". And Koenigsberger seemed to echo this very point when he added that it was "not possible to construct overall theories" on the question of clientage and patronage. Surely, it might be feasible to suggest a general definition of sorts which would emphasize the reciprocity and social asymmetry of patron-client relations. But the utility of such a definition for historians is likely to be limited because it does not take into account local, specific, idiosyncratic conditions prevailing in different polities. Parenthetically, one should add here the obvious point that the diversity of economic and social conditions and of political and cultural traditions was as great in Italy as in the German Empire and that attempts to force the Italian scene into a rigid theoretical explanation will likely lead to disagreements and contrasts similar to those already encountered in our discussion.

What, then, should we do? In seeking to overcome the conceptual dead-end into which I seem to have backed myself in thinking about the question of patronage, I was struck by Pietro Schiera's contribution to our discussion. For Schiera, if I understood him correctly, suggested that patronage is difficult to define precisely because it is not an institution, but rather because it facilitates the functioning of social and govern-

${ }^{20}$ Jean-Claude Waquet, De la corruption - Morale et Pouvoir à Florence aux XVII et XVIII ${ }^{\mathrm{e}}$ siècles (Paris 1984). 
mental institutions. Metaphorically, it can be thought of as a lubricant of sorts; or, if one will, an engine easily adaptable from situation to situation. In my mind, I have now come to think of it in somewhat the same terms that I use to think of ritual: ever present in all societies, nonetheless, it assumes forms particular to each society. Ritual seems to respond to some deeply felt need of beings to order their social exchanges and their private lives according to some socially determined forms. One should leave anthropologists, socio-biologists, ethologists and other such sages to tell us whether patronage also responds to similar needs. Let me simply say here that the example of Italy from Roman times to our very own days provides us a case study of the ubiquity of patronal-clientelar ties. And one starts with Rome and not earlier, not because the Etruscans were more virtuous and noble but because the evidence on them is so scanty. If what I have just said were so then what becomes important in the study of patronage is the very local situation examined and in whose context patronal relations were developed. The economy, social relations, political structures, cultural traditions, religious beliefs - all these provided a concrete historical context within which patronclient relations were forged. And not the least virtue of the three papers submitted to our session is that their authors trace with such admirable precision the local conditions which, in Piedmont, in Lombardy and in the Mezzogiono gave rise to patronclient relations in the early modern age. 